\title{
Composition and structure of the larval fish community in the NW Iberian upwelling system during the winter mixing period
}

\author{
J. M. Rodriguez ${ }^{1, *}$, A. Cabrero ${ }^{2}$, J. Gago ${ }^{2}$, A. Garcia ${ }^{3}$, R. Laiz-Carrion ${ }^{3}$, C. Piñeiro' ${ }^{2}$, \\ F. Saborido-Rey ${ }^{4}$ \\ ${ }^{1}$ Instituto Español de Oceanografía, Centro Oceanográfico da Gijón 33212, Gijón, Spain \\ ${ }^{2}$ Instituto Español de Oceanografía, Centro Oceanográfico de Vigo 36390, Vigo, Spain \\ ${ }^{3}$ Instituto Español de Oceanografía, Centro Oceanográfico de Málaga, 29640 Fuengirola, Málaga, Spain \\ ${ }^{4}$ Instituto de Investigaciones Marinas (CSIC), Eduardo Cabello 6, 36208 Vigo, Spain
}

\begin{abstract}
The composition and structure of the larval fish community (LFC) in the NW Iberian upwelling system in late winter 2012 were examined, and the influence of abiotic and biotic factors on the horizontal distribution of fish larvae and on the horizontal structure of the LFC was investigated. The LFC, composed of 62 taxa (59 species and 3 genera) in 28 families, was dominated by Micromesistius poutassou followed by Scomber scombrus, Merluccius merluccius and Maurolicus muelleri. Multivariate analyses identified depth, sea surface temperature, geostrophic velocity and mesozooplankton biomass as the environmental factors involved in explaining variability in the LFC parameters (larval fish abundance, species richness and diversity) and revealed that the LFC was structured into coastal and slope larval fish assemblages. The main factor defining these assemblages was depth. However, the unusual coastal downwelling that occurred during the study would have participated in creating them and in maintaining assemblage boundaries, so that the importance of depth to the cross-shelf structuring of the LFC may have been overestimated. Our results suggest that larval fish assemblages in regions of coastal upwelling are driven by coastal downwelling during the winter mixing period and support the idea that fish larvae act as short-term $(\sim 10 \mathrm{~d})$ biological tracers of the hydrography of the region during that period.
\end{abstract}

KEY WORDS: NW Iberian upwelling system · Hydrography · Winter mixing period · Downwelling • Ichthyoplankton · Larval fish community

\section{INTRODUCTION}

The NW Iberian peninsula is the northern border of the coastal upwelling that extends along the eastern coasts of the North Atlantic. At these latitudes, northerly winds, which are favourable to coastal upwelling, predominate during spring and summer, and the surface current over the shelf flows equatorward (Wooster et al. 1976, Haynes \& Barton 1990). Southerly winds, which are favourable to coastal downwelling, prevail in autumn and winter, and the

\footnotetext{
*Corresponding author: j.m.rodriguez@gi.ieo.es
}

surface current over the shelf flows poleward (Wooster et al. 1976, Haynes \& Barton 1990). Apart from this seasonal pattern, the region, like other eastern boundary systems, is under the influence of a poleward flow located over the slope, viz. the Iberian Poleward Current (IPC). This is an unstable flow that transports warm and salty waters and that is rich in mesoscale features, like eddy shedding and front formation (Peliz et al. 2003, Relvas et al. 2007). In addition, within this general pattern, there is great variability in the atmospheric forcing that occurs in the

() The authors 2015. Open Access under Creative Commons by Attribution Licence. Use, distribution and reproduction are unrestricted. Authors and original publication must be credited. 
form of pulses, at a time scale shorter than seasonal (e.g. Torres et al. 2003). This results in complex variability, on short time scales, of the hydrography and circulation over the shelf and slope regions (Torres et al. 2003, Torres \& Barton 2007). This area may also be occupied either by the warmer and saltier eastern North Atlantic central water of subtropical origin (ENACWst), transported by the IPC, or by the colder and fresher eastern North Atlantic central water of subpolar origin (ENACWsp). The border between these 2 water masses forms a sub-surface thermohaline front that may have important implications for larval fish distribution and whose along-shelf location depends on the time of the year and on coastal climatological factors (Gonzalez-Nuevo \& Nogueira 2005, Rodriguez et al. 2009). Thus, this area is a region of relatively high mesoscale activity characterized by the development of different mesoscale hydrographic features.

These features, along with marine currents, play a major role in the horizontal distribution and survival of fish larvae. In coastal upwelling regions, the surface offshore and onshore Ekman flows associated with coastal upwelling and downwelling, respectively, are also important in larval fish distribution (Parrish et al. 1981, Norcross \& Shaw 1984, Smith et al. 1999). Other abiotic and biological factors, such as water temperature (Smith et al. 1999, Olivar et al. 2010), the spawning location and spawning strategy of adult fishes (Parrish et al. 1981, Norcross \& Shaw 1984), the vertical distribution (John \& Re 1995, Olivar \& Sabatés 1997) and the vertical migratory behaviour (Parrish et al. 1981, Paris \& Cowen 2004) of fish larvae and trophic interactions (Govoni 2005, Olivar et al. 2010) also play a role. In consequence, processes and factors that influence the horizontal distribution, survival and abundance of fish larvae would also define the horizontal structure of the larval fish community (LFC).

In spite of the importance of the early life stages for marine fish population dynamics and for the planktonic ecosystem, little is known about the LFC off the NW Iberian peninsula, especially during the winter mixing period. Thus, most of the ichthyoplankton surveys carried out along the coasts of the NW and northern Iberian Peninsula have had the aim of generating fishery-independent stock assessments. Consequently, most ichthyoplankton studies in the area have been focussed on commercially important species, especially Sardina pilchardus (e.g. Garcia et al. 1992, Lopez-Jamar et al. 1995). To our knowledge, only Rodriguez et al. (2009) have investigated the LFC of this region, but that study was carried out in spring. In nearby regions, studies of the LFC are also scarce (John \& Re 1995, Rodriguez 2008, Garrido et al. 2009, Rodriguez et al. 2011), and none was carried out during the winter mixing period. Other studies were restricted to very littoral regions (Azeiteiro et al. 2006) or were carried out in the Galician rias (LopezJamar 1977, Ferreiro \& Labarta 1988). Thus, ours is the first study of the LFC carried out in this region during the winter mixing period. The aims of this study were (1) to describe the composition and structure of the LFC off the NW Iberian peninsula, and (2) to analyse the influence that abiotic (depth, sea surface salinity, sea surface temperature, geostrophic velocity and dynamic height) and biotic (micro- and mesozooplankton biomass) factors have on the horizontal distribution of fish larvae and in determining the horizontal structure of the LFC, during the winter mixing period. We also hypothesized that fish larvae are good tracers of the hydrography of the region on a short time scale (several days) during the winter mixing period.

\section{MATERIALS AND METHODS}

This study is based on hydrographic data and zooplankton samples collected during the 'Cramer 1203' cruise, carried out off the NW Iberian peninsula in late winter, from 28 February to 9 March 2012 (Fig. 1). In total, we sampled 80 stations, arranged in 15 transects perpendicular to the coastline, including the shelf and slope regions, from around 40 to $500 \mathrm{~m}$

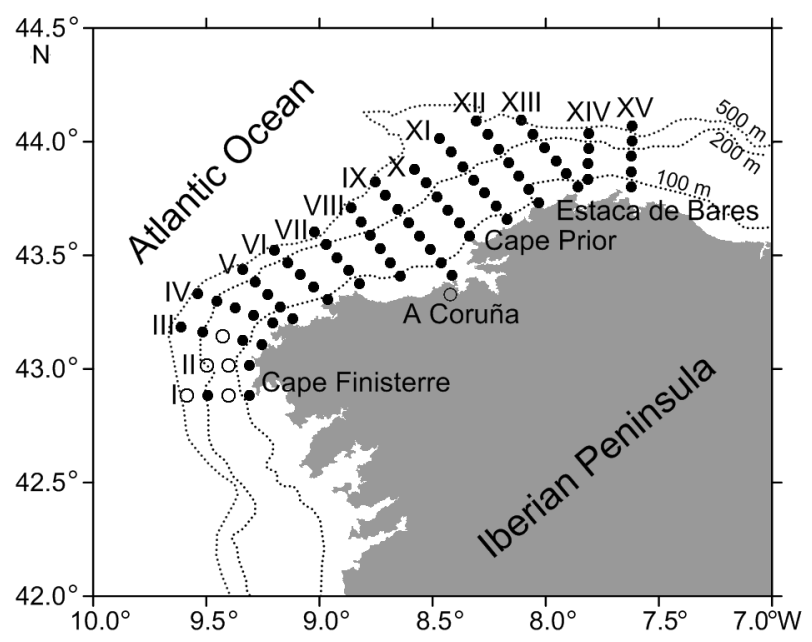

Fig. 1. Study area and sampling stations. Open circles represent stations sampled for hydrography; black circles are stations sampled for hydrography and ichthyoplankton. Transects are indicated by roman numerals 
depth (Fig. 1). Transects were 8 nautical miles apart, and the distance between stations was 4 miles.

At every station, vertical profiles of conductivity, temperature and pressure were recorded with a SeaBird $25 \mathrm{CTD}$ to $200 \mathrm{~m}$ depth, or to $5 \mathrm{~m}$ above the bottom at shallower stations and to $400 \mathrm{~m}$ depth at selected stations.

Local winds were measured by the 'Puertos del Estado' buoy, located at $43.50^{\circ} \mathrm{N}, 9.21^{\circ} \mathrm{W}$. Daily upwelling index values were provided by the Spanish Institute of Oceanography (www.indicedeafloramiento.ieo.es). These values were calculated using the sea level pressure obtained from the Fleet Numerical Meteorology and Oceanography Center (www.usno.navy.mil/FNMOC), to determine the geostrophic wind in a cell centered at $44^{\circ} \mathrm{N}, 9^{\circ} \mathrm{W}$. Positive values of the upwelling index correspond to upwelling, while negative values correspond to downwelling.

Zooplankton samples were collected with a Calvet net $(25 \mathrm{~cm}$ mouth diameter and $55 \mu \mathrm{m}$ mesh size) in vertical hauls, from $200 \mathrm{~m}$ depth or from $10 \mathrm{~m}$ above the bottom, at shallower stations, to the surface. Samples were filtered immediately through 55 and $200 \mu \mathrm{m}$ mesh filters to separate the micro- (55-200 $\mu \mathrm{m})$ and mesozooplankton $(>200 \mu \mathrm{m})$ fractions. The micro- and mesozooplankton fractions were frozen at $-20^{\circ} \mathrm{C}$. In the laboratory, micro- and mesozooplankton samples were dried in an oven at $60^{\circ} \mathrm{C}$ to obtain dry weight. Micro- (MiB) and mesozooplankton (MeB) dry weight biomass values were standardised to $\mathrm{mg} \mathrm{m}^{-2}$.

Stratified ichthyoplankton samples at 5 predefined and fixed depth strata $(0-20,20-40,40-60,60-100$ and 100-200 m depth) were collected with a multiple opening/closing MultiNet MiDi, $50 \times 50 \mathrm{~cm}$ aperture, equipped with 5 nets of $200 \mu \mathrm{m}$ mesh size. Ichthyoplankton tows were oblique, from $200 \mathrm{~m}$ depth (or $\sim 10 \mathrm{~m}$ above the bottom at shallower stations) to the surface. Haul depth was monitored during every sampling by a Scanmar depth sensor mounted on the wire cable. The volume of water filtered in each stratum was measured by an electronic flowmeter located in the mouth of the net. Samples were immediately preserved in a $5 \%$ solution of buffered formalin and seawater. In total, 75 stations were sampled for ichthyoplankton but, because of sample loss, only 73 were included in this study (Fig. 1).

In the laboratory, all fish larvae were sorted from the samples and identified to the lowest taxonomic level possible. Larval fish abundances (measured as the number of larvae per $10 \mathrm{~m}^{2}$ ), were calculated for each station by integrating the volume of water fil- tered and the number of larvae collected at each depth stratum. Fish larvae of the most abundant species were measured for standard length, using the ImageJ $1.45 \mathrm{~s}$ image analysis software. No corrections were made for shrinkage. To study the cross-shelf and the along-shelf distribution of larval sizes of the most abundant species, the study area was divided into 3 depth strata $(<100,100-200$ and $>200$ m bottom depth), and transects were grouped into 3 groups (transects I-V, VI-X and XI-XV).

\section{Data analysis}

Dynamic height (DH) was calculated from vertical profiles of temperature, salinity and pressure using $400 \mathrm{~m}$ depth as the reference level. At shallower stations, or when data were recorded only to $200 \mathrm{~m}$, the deepest level sampled by the CTD was assigned the density anomaly of the same depth at the adjacent deeper station. Geostrophic velocities (GV) were obtained from DH. DH was used as an indicator of eddy regions, because this variable is higher than average in anticyclonic regions, lower than average in cyclonic eddy regions and shows gradients in frontal regions (Lindo-Atichati et al. 2012 and references therein). GV at $10 \mathrm{~m}$ depth was used as an indicator of eddy boundaries and frontal regions, because GV should be higher in these regions (Peliz et al. 2002, Bakun 2006).

Hydrographic fronts, perpendicular to the coast, were located following the method proposed by Gonzalez-Nuevo et al. (2007). This method is based on the automatic detection of the change of the subsurface hydrographic properties (temperature and salinity) along the continental shelf, as represented by the variable 'spiciness' (Flament 2002), which has higher values for hot and salty ('spicy') water and is a useful indicator of water masses. 'Spiciness' was calculated at $100 \mathrm{~m}$ depth in order to avoid the influence that atmospheric conditions and continental freshwater inputs have on the surface layer water masses and to characterise the underlying water masses of the region (Gonzalez-Nuevo \& Nogueira 2005).

Surface current fields were obtained from the Regional Ocean Model System (ROMS) of the Spanish Institute of Oceanography (available at: www. indicedeafloramiento.ieo.es). Settings of the model, with a horizontal resolution of $4 \mathrm{~km}$ and 40 vertical levels, are described in Otero et al. (2013).

Differences in larval size between depth strata and between transect groups were assessed with ANOVA (species with measured larvae at the 3 
depth strata and/or the 3 transect groups) or Student's $t$-test for independent samples (species with measured larvae at only 2 depth strata and/or 2 transect groups). ANOVA was followed, when necessary, by a post hoc Tukey test. Larval fish diversity was calculated for each station using the ShannonWiener diversity index.

\section{Multivariate analysis}

Multiple regression analysis was used to assess the relative influence of the environmental variables on total larval fish abundance, number of taxa (an estimate of species richness) and larval fish diversity. The environmental variables considered in these analyses were bottom depth at each station (depth), sea surface temperature (SST), DH, GV, MiB and MeB. Sea surface salinity (SSS) was not included because it was highly correlated with $\mathrm{SST}(\mathrm{r}=0.70$, $\mathrm{p}<0.01$ ). Values of 'SST' and 'SSS' were actually from $10 \mathrm{~m}$ depth because CTD profiles did not always start at the surface and, besides, the upper layer was wellmixed. The variables to be included in the models were selected using Akaike's information criterion, following a stepwise forward selection procedure. Prior to the analyses, variables were tested for normality and $\log _{10}(x+1)$ transformed, if necessary.

Cluster analysis in conjunction with non-metric multidimensional (nMDS) ordination was used to identify larval fish assemblages and taxon groups. Both analyses were performed on a Bray-Curtis similarity matrix, generated from the square root transformed data of larval fish abundances. Only taxa with a relative abundance of $>0.2$ larvae $10 \mathrm{~m}^{-2}$ and that appeared in $>10 \%$ of the ichthyoplankton stations were included in these analyses. Data were transformed to reduce the weighting of more abundant species (Field et al. 1982, Clarke 1993). Hierarchical agglomerative clustering with group-average linking and complete linkage, carried out on the Bray-Curtis similarity matrix, was used to delineate larval fish assemblages and taxon groups, respectively. Arbitrary cut-off levels were chosen on dendrograms to produce ecologically interpretable clusters (Field et al. 1982, Auth \& Brodeur 2006). The adequacy of the classification analyses was checked by superimposing clustering results on nMDS plots, generated from the same similarity matrix (Field et al. 1982, Clarke 1993, Auth \& Brodeur 2006). A 2-dimensional ordination approach was adopted because the stress level $(\leq 0.19)$ was acceptably low, considering that we used the nMDS ordination to check the adequacy of the classification analyses (Field et al. 1982, Clarke 1993).

The relationship between environmental factors and larval fish species was assessed with canonical correspondence analyses (CCA; ter Braak \& Verdonschot 1995, ter Braak \& Smilauer 2002). Taxa included in CCA analysis were the same as those included in the analysis of the LFC structure. Larval fish abundances were $\log _{e}(x+1)$ transformed before analysis. The explanatory variables were the same as in multiple regression analysis. Forward stepwise selection of explanatory variables was carried out using the Monte Carlo permutation test (9999 permutations) in CANOCO. Only those variables that significantly $(\mathrm{p}<0.05)$ explained the species distribution pattern were included in the analysis. Canonical axes were also tested for significance with the Monte Carlo permutation test.

Diversity index, cluster analysis and nMDS ordination were performed with PRIMER 6.1.6 (Clarke \& Warwick 2001). The CCA ordination was accomplished using CANOCO Version 4.56 (ter Braak \& Smilauer 2002), while ANOVA, Student's $t$-test and multiple regression analyses were run in the free statistical software R 3.0.2 (R Development Core Team 2014)

\section{RESULTS}

\section{Environmental variables}

The wind regime during February and March 2012 was quite anomalous for this time of the year, with northerly winds favourable to upwelling blowing persistently during February. However, during the study period, positive values of the daily upwelling index alternated with relatively high negative values (Fig. 2). This resulted in average values of the upwelling index of $554 \mathrm{~m}^{3} \mathrm{~s}^{-1} \mathrm{~km}^{-1}$ for February and $-39.7 \mathrm{~m}^{3} \mathrm{~s}^{-1} \mathrm{~km}^{-1}$ for the study period, which were far from the historical (1967-2012) average values of $-692 \mathrm{~m}^{3} \mathrm{~s}^{-1} \mathrm{~km}^{-1}$ for February and $-303 \mathrm{~m}^{3} \mathrm{~s}^{-1} \mathrm{~km}^{-1}$ for March.

The water column was well mixed, and thus the difference in mean temperatures and salinities between 10 and $200 \mathrm{~m}$ depths was $0.25^{\circ} \mathrm{C}$ and 0.03 , respectively. SST and SSS decreased from south to northeast (Fig. 3).

$\mathrm{GV}$ values were weak, below $10 \mathrm{~cm} \mathrm{~s}^{-1}$, with the highest values recorded in the northeastern border of the study area (Fig. 3). DH showed little variability; the difference between the maximum and minimum values was only $0.25 \mathrm{~cm}$. 


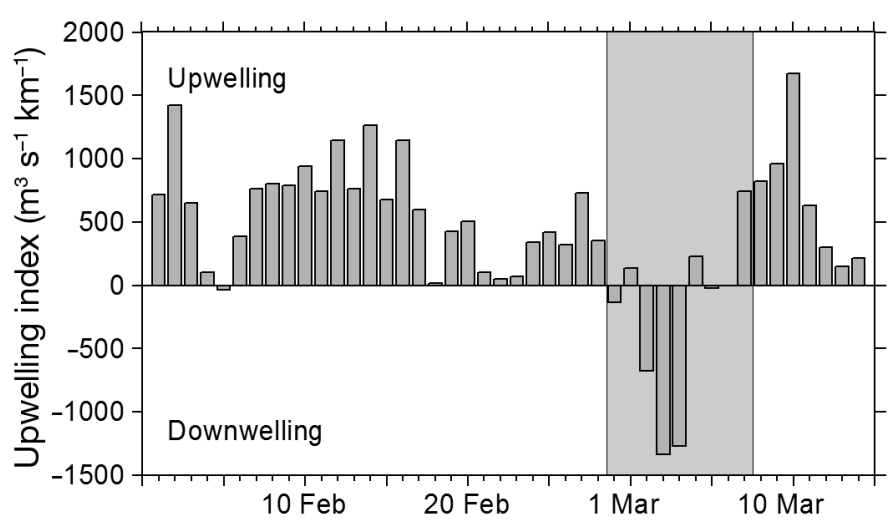

Fig. 2. Daily upwelling index calculated at $44^{\circ} \mathrm{N}, 9^{\circ} \mathrm{W}$, from 1 February to 15 March 2012. The shaded region denotes the time of the cruise

The along-shelf distribution of the variable 'spiciness' showed constant values from Cape Finisterre to Cape Prior, beyond which it decreased uniformly (Figs. $1 \& 4$ ), revealing the presence of a sub-surface thermohaline front that was also present in the surface layer. Surface waters southwest of Transect X, off Cape Prior (Figs. 1 \& 3), were slightly warmer and saltier (average SST and SSS of $12.75^{\circ} \mathrm{C}$ and 35.80 ) than surface waters northeast of this transect (average SST and SSS of $12.50^{\circ} \mathrm{C}$ and 35.77). Differences between temperature and salinity on either side of Cape Prior, although small, were significant ( $t$-test, $\mathrm{p}<0.01$ in both cases).

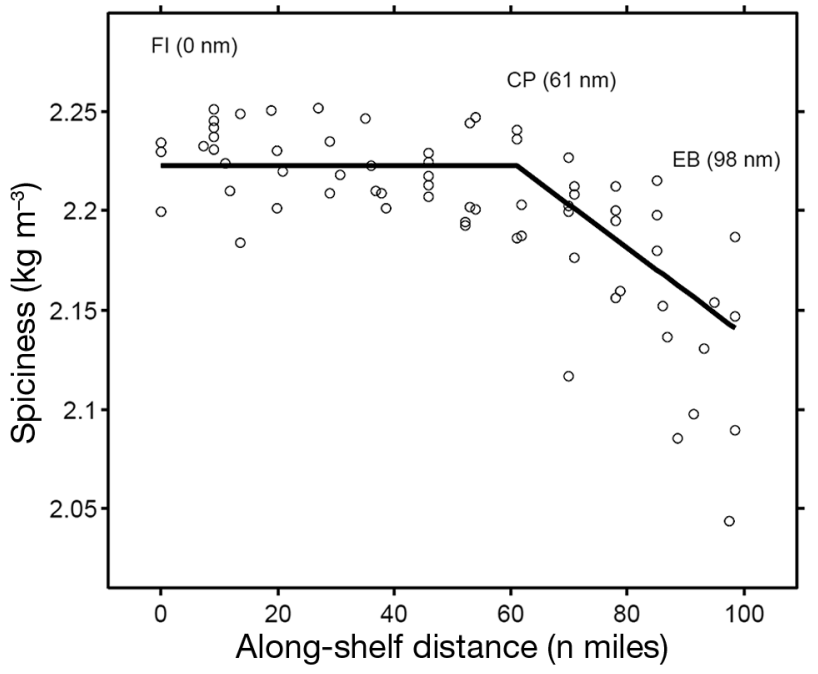

Fig. 4. Along-shelf distribution of the 'spiciness' variable showing a subsurface front located around Cape Prior. FI: Cape Finisterre, CP: Cape Prior, EB: Cape Estaca de Bares. See Fig. 1 for their geographical location



Fig. 3. Horizontal distribution of sea surface temperature (SST, ${ }^{\circ} \mathrm{C}$ at $10 \mathrm{~m}$ depth), sea surface salinity (SSS, salinity at $10 \mathrm{~m}$ depth) and geostrophic velocity (GV, $\mathrm{cm} \mathrm{s}^{-1}$ at $10 \mathrm{~m}$ depth). Black dots represent sampling stations

The sea surface maps of modelled current show a northeasterly flow at the beginning of the cruise, located over the shelf break (Fig. 5a). By the middle of the cruise, this flow was located over the shelf (Fig. 5b), but at the end of the cruise, it was not possible to determine a predominant direction of the surface flow (Fig. 5c).

MiB values lay between 7.3 and $4939.0 \mathrm{mg} \mathrm{m}^{-2}$, with a mean of $589.1 \mathrm{mg} \mathrm{m}^{-2}$, while $\mathrm{MeB}$ values ranged from 425.4 to $7681.6 \mathrm{mg} \mathrm{m}^{-2}$, with a mean of 

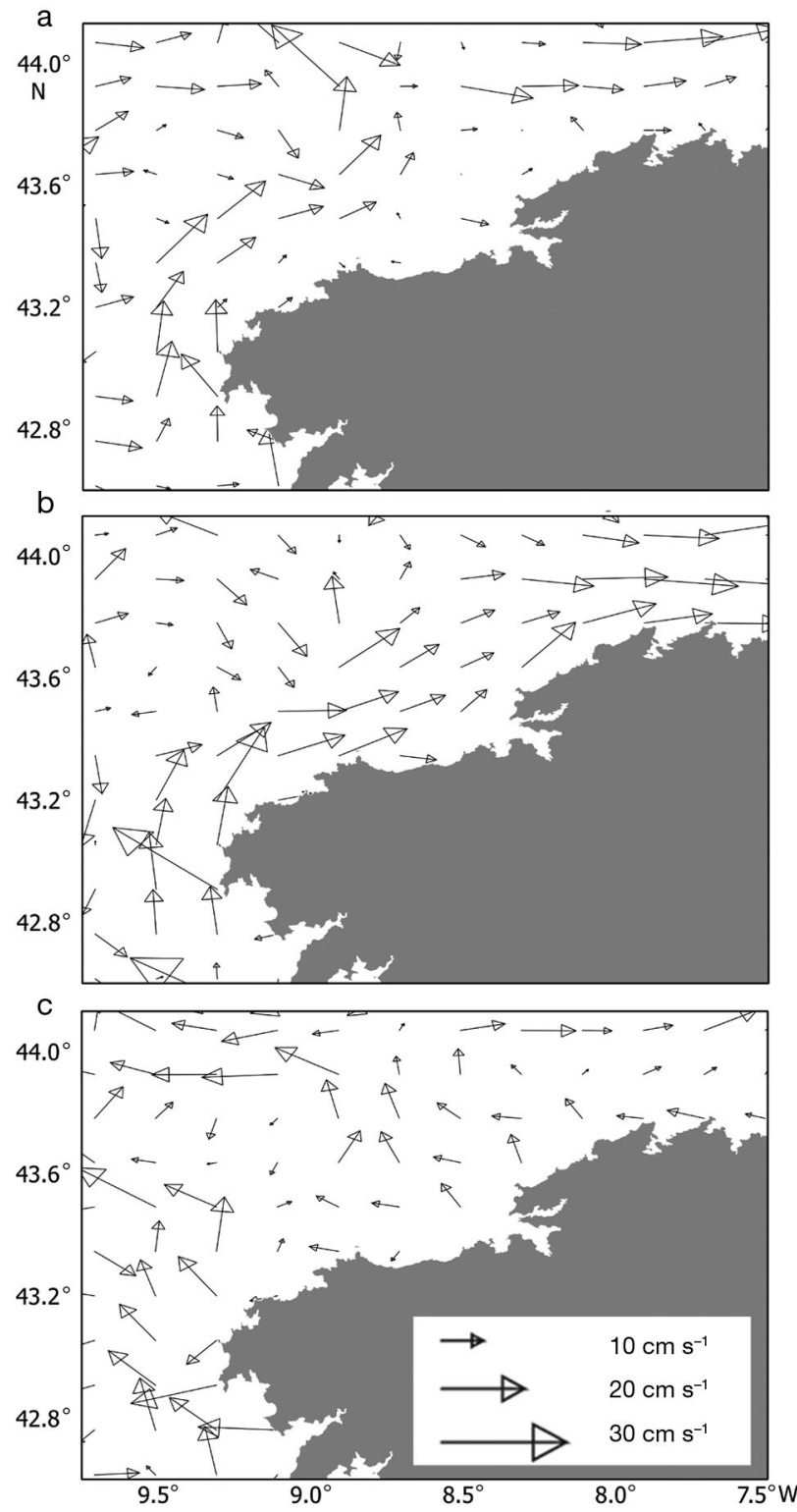

Fig. 5. Sea surface current maps at the (a) beginning (29 February), (b) middle (4 March) and (c) end (8 March) of the cruise

$2413.1 \mathrm{mg} \mathrm{m}^{-2}$. The horizontal distribution of $\mathrm{MeB}$ increased from south to north and towards the coast (Fig. 6).

\section{LFC}

In total, we collected 9117 larvae belonging to 62 taxa (59 species and 3 genera) in 28 families (Table 1). Micromesistius poutassou was the most abundant species, accounting for $40.92 \%$ of the total larval fish abundance. It was followed by Scomber scombrus (18.15\%) and Merluccius merluccius (4.52\%). Only a single mesopelagic (oceanic-slope) species, Maurolicus muelleri $(2.48 \%$ of the total larval fish abundance), was among the species that contributed $>1 \%$ to the total larval fish abundance. The most ubiquitous species was $M$. merluccius, which appeared at $73.0 \%$ of the ichthyoplankton stations; it was followed by $M$. poutassou (71.6\%) and M. muelleri $(68.9 \%)$. S. scombrus was captured at only $18.2 \%$ of the ichthyoplankton stations.

Larval fish abundance ranged between 4.58 and 26147.26 larvae $10 \mathrm{~m}^{-2}$ with a mean of 939.77 larvae $10 \mathrm{~m}^{-2}$. Abundance increased from south to north and towards the coast, so that the highest abundance was recorded at the northeastern border of the study area (Fig. 6). The variables significant in explaining variability in larval fish abundance were SST, followed by depth and MeB. These variables jointly explained $63 \%$ of the variance in larval fish abundance. This LFC parameter decreased with increasing depth and SST and increased with increasing MeB (Table 2).

Larvae of the 6 most abundant fish species showed 2 patterns of horizontal distribution. Larvae of coastalshelf spawning species (e.g. S. scombrus, Sardina pilchardus and Trisopterus minutus) were restricted to the coastal-shelf region, while larvae of slope spawning species (e.g. M. merluccius, M. muelleri and $M$. poutassou) showed a wider horizontal distribution (Fig. 6).

The cross-shelf and the along-shelf distribution of mean larval sizes of the 6 species measured (Fig. 7) show that the size of $M$. muelleri, $M$. merluccius and M. poutassou larvae increased shoreward (ANOVA, $\mathrm{p}<0.01$; Tukey test, $\mathrm{p}<0.05)$. For 3 species $(S$. pilchardus, S. scombrus and T. minutus) with no larval size data available (no measurable larvae were caught for S. pilchardus and T. minutus, and no larvae were caught for $S$. scombrus) in the 200-500 m depth stratum, larvae were larger in the 100-200 m depth stratum than in the region $<100 \mathrm{~m}$ depth, although size differences were only significant for $S$. pilchardus and $S$. scombrus ( $t$-test, $\mathrm{p}<0.05)$. In the along-shelf direction, larvae of $M$. muelleri, $M$. merluccius and $M$. poutassou were larger in the central part of the study area (ANOVA, p < 0.05). However, Tukey's post hoc test revealed significant differences $(p<0.05)$ for $M$. merluccius only (transect group I-V $<$ transect group $\mathrm{XI}-\mathrm{XV}<$ transect group VI-X). The larval size of $S$. pilchardus increased southward (ANOVA, $\mathrm{p}<0.05$, Tukey test, $\mathrm{p}<0.05$ ). Larval sizes of $T$. minutus were larger in the transect group XI-XV ( $t$-test, $\mathrm{p}<0.01)$. It must be added that $S$. scombrus was found only at the northern border of the study area (Fig. 6). 


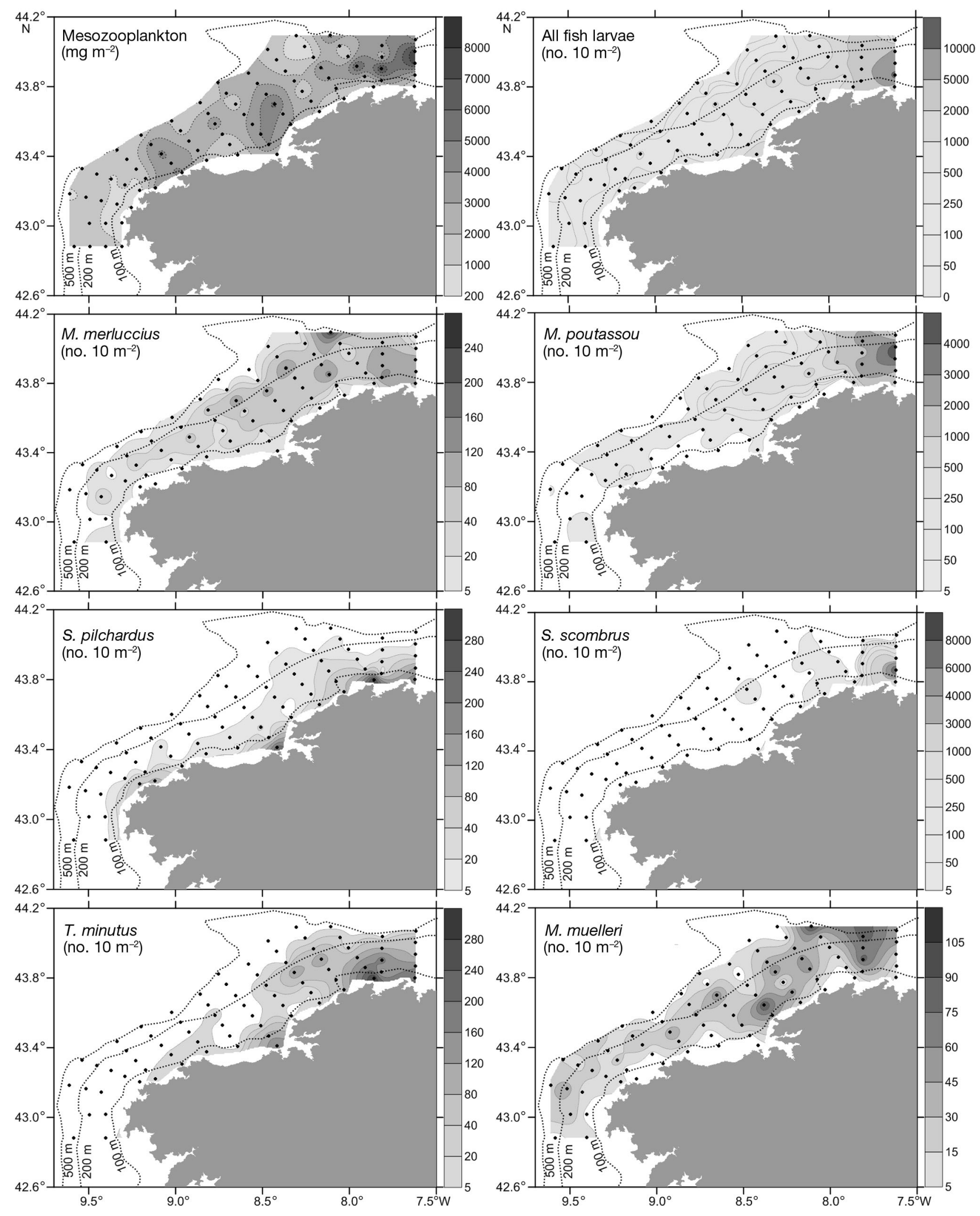

Fig. 6. Horizontal distribution of mesozooplankton biomass (MeB) and fish larvae. See Table 1 for full species names. Black dots represent sampling stations 
Species richness ranged from 1 to 32 , with an average value of 13.8. This community parameter increased from south to north and towards the coast
(Fig. 8a). Depth followed by SST and MeB were the variables significant in explaining species richness variance, and together accounted for $75 \%$ of this

Table 1. Alphabetical list of larval fish families collected off the Galician coast during the Cramer 1203 cruise. Code: canonical correspondence analysis (CCA) taxon code; RA: taxon relative abundance (\%); \%Oc: percentage of occurrence (\%)

\begin{tabular}{|c|c|c|c|c|c|c|c|}
\hline Family and species & Code & RA & $\% \mathrm{Oc}$ & Family and species & Code & RA & $\% \mathrm{Oc}$ \\
\hline Family Ammodytidae & & & & Family Lotidae & & & \\
\hline Ammodytes tobianus & At & 0.74 & 20.3 & Gaidropsarus mediterraneus & $G m$ & 0.90 & 28.4 \\
\hline Gymnammodytes semisquamatus & & 0.17 & 13.5 & Gaidropsarus vulgaris & GV & 1.33 & 23.0 \\
\hline Hyperoplus lanceolatus & $H l$ & 0.48 & 16.2 & Family Merlucciidae & & & \\
\hline Family Argentinidae & & & & Merluccius merluccius & Mme & 4.52 & 73.0 \\
\hline Argentina sphyraena & As & 0.94 & 43.2 & Family Moronidae & & & \\
\hline Family Bathilagidae & & & & Dicentrarchus labrax & $D l$ & 0.36 & 17.6 \\
\hline Melanolagus bericoides & & 0.01 & 1.4 & Family Myctophidae & & & \\
\hline Unidentified spp. & & 0.01 & 1.4 & Benthosema glaciale & $B g$ & 0.40 & 23.0 \\
\hline Family Blennidae & & & & Lampanyctus crocodilus & & 0.06 & 6.8 \\
\hline Coryphoblennius galerita & & 0.03 & 2.7 & Myctophum punctatum & & 0.16 & 18.9 \\
\hline Parablennius gattorugine & & 0.07 & 6.8 & Notoscopelus resplendens & & 0.15 & 16.2 \\
\hline Parablennius pilicornis & & 0.03 & 2.7 & Family Paralepididae & & & \\
\hline Blennidae sp. 2 & Bsp2 & 0.46 & 21.6 & Paralepis atlantica & & 0.02 & 2.7 \\
\hline Family Bothidae & & & & Family Phycidae & & & \\
\hline Arnoglossus laterna & $A l$ & 0.80 & 27.0 & Phycis blennoides & & 0.09 & 8.1 \\
\hline Zeugopterus punctatus & & 0.13 & 10.8 & Phycis phycis & & 0.11 & 8.1 \\
\hline Unidentified spp. & & 0.04 & 2.7 & Family Scombridae & & & \\
\hline Family Callionymidae & & & & Scomber scombrus & Ss & 18.15 & 23.0 \\
\hline Callionymus spp. & Cspp & 1.48 & 47.3 & Family Scophthalmidae & & & \\
\hline Family Carapidae & & & & Lepidorhombus boscii & Lbo & 1.15 & 40.5 \\
\hline Echiodon dentatus & & 0.05 & 4.1 & Lepidorhombus whiffiagonis & $L w$ & 0.76 & 20.3 \\
\hline Family Carangidae & & & & Phrynorhombus norvegicus & & 0.05 & 5.4 \\
\hline Trachurus trachurus & $T t$ & 1.75 & 25.7 & Family Scorpaenidae & & & \\
\hline Family Clupeidae & & & & Helicolenus dactylopterus & & 0.05 & 5.4 \\
\hline Sardina pilchardus & $S p$ & 2.38 & 43.2 & Family Soleidae & & & \\
\hline Family Cottidae & & & & Microchirus variegatus & $M v$ & 1.35 & 43.2 \\
\hline Taurulus bubalis & & 0.02 & 1.4 & Solea solea & Sso & 0.27 & 16.2 \\
\hline Family Gadidae & & & & Family Sparidae & & & \\
\hline Gadiculus argenteus & $G a$ & 1.32 & 43.2 & Boops boops & $B b$ & 1.32 & 25.7 \\
\hline Micromesistius poutassou & $M p$ & 40.92 & 71.6 & Diplodus annularis & & 0.02 & 1.4 \\
\hline Merlangius merlangus & & 0.02 & 1.4 & Diplodus spp. & & 0.07 & 6.8 \\
\hline Pollachius pollachius & Ppo & 0.30 & 20.3 & Pagellus bogaraveo & & 0.14 & 9.5 \\
\hline Trisopterus luscus & $T 1$ & 0.71 & 29.7 & Spondyliosoma cantharus & $S C$ & 0.60 & 18.9 \\
\hline Trisopterus minutus & $T m$ & 3.48 & 43.2 & Unidentified spp. & & 0.04 & 2.7 \\
\hline Unidentified spp. & & 0.12 & 9.5 & Family Sternoptychidae & & & \\
\hline Family Gobiidae & & & & Maurolicus muelleri & $M m$ & 2.48 & 68.9 \\
\hline Crystallogobius linearis & & 0.05 & 5.4 & Family Sygnathidae & & & \\
\hline Lebetus guilleti & $L g$ & 0.54 & 32.4 & Entelurus aequoraeus & & 0.01 & 1.4 \\
\hline Pomatoschistus marmoratus & & 0.11 & 9.5 & Family Trachinidae & & & \\
\hline Pomatoschistus microps & $P m$ & 0.21 & 16.2 & Trachinus vipera & & 0.04 & 5.4 \\
\hline $\begin{array}{l}\text { Pomatoschistus minutus } \\
\text { Pomatoschistus pictus }\end{array}$ & $P m i$ & $\begin{array}{l}1.30 \\
0.02\end{array}$ & $\begin{array}{c}39.2 \\
1.4\end{array}$ & Family Triglidae & & & \\
\hline Pomatoschistus spp. & $P$ spp & 0.97 & $\begin{array}{c}1.4 \\
31.1\end{array}$ & Eutrigla gurnardus & $E g$ & 0.94 & 40.5 \\
\hline Unidentified spp. & & 0.39 & 27.0 & Lepidotrigla cavillone & & 0.03 & 2.7 \\
\hline Family Labridae & & & & Family Pleuronectidae & & & \\
\hline Labrus bergylta & $L b$ & 0.66 & 14.9 & Platichthys flesus & & 0.09 & 2.7 \\
\hline Labrus mixtus & $L m$ & 0.22 & 13.5 & Unidentified spp. & & 0.04 & 2.7 \\
\hline Symphodus melops & & 0.06 & 5.4 & Unidentified spp. & & 3.29 & 64.9 \\
\hline Labridae sp. 4 & & 0.03 & 4.1 & & & & \\
\hline
\end{tabular}




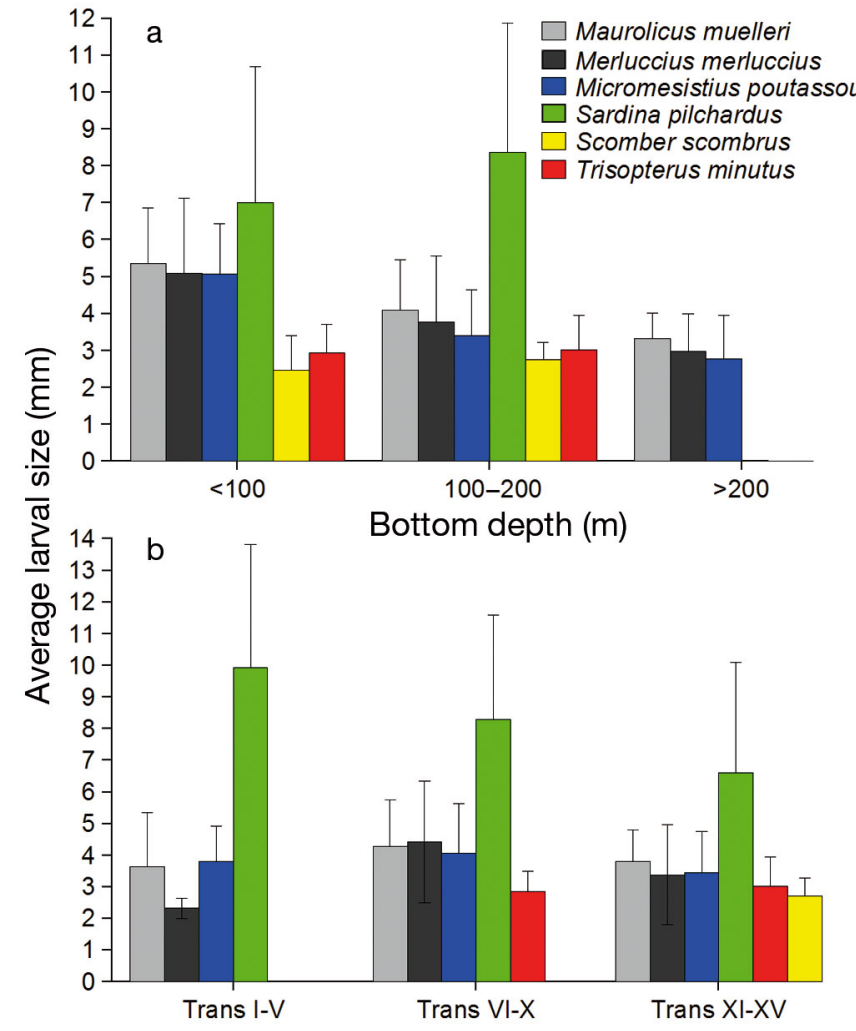

Fig. 7. (a) Cross-shelf and (b) along-shelf distribution of mean larval sizes of the 6 most abundant species. Trans: transects. Error bars represent the standard deviation

variance (Table 2). Species richness decreased with increasing depth and SST, and increased with MeB (Table 2).

The relatively high larval fish diversity ranged from values of 0 to 3.1 with a mean of 1.8. This community parameter followed a similar pattern of horizontal distribution to that of the species richness (Fig. 8b). The most remarkable difference between these distributions was the relatively low values recorded for larval fish diversity along the northeastern border of the study area, where the highest values of species richness were recorded (Fig. 8). Only depth and GV were significant in explaining larval fish diversity variance, accounting for $39 \%$ of the total. Diversity diminished with increasing depth and GV.

Larval fish abundance was significantly and positively correlated with species richness $(\mathrm{r}=0.89$, $\mathrm{p}<$ $0.01)$ and larval fish diversity $(\mathrm{r}=0.39, \mathrm{p}<0.01)$. The last 2 LFC parameters were also correlated with each other $(\mathrm{r}=0.73, \mathrm{p}<0.01)$.

Cluster analysis identified 2 larval fish assemblages at a similarity level of $17 \%$ (Fig. 9a). The nMDS ordination produced the same results (Fig. 9b). Assemblages were named after the location of the stations
Table 2. Best multiple regression models explaining the relative influence of the environmental variables, depth, sea surface temperature (SST), geostrophic velocity (GV) and mesozooplankton biomass (MeB) on larval fish abundance $\left[\log _{10}\right.$ (number of larvae $10 \mathrm{~m}^{-2}$ )], species richness $\left[\log _{10}\right.$ (number of taxa)] and diversity index variability. Numbers in parentheses are standard errors. ${ }^{*} \mathrm{p}<0.05,{ }^{* *} \mathrm{p}<0.01$, ${ }^{* * *} \mathrm{p}<0.001$

\begin{tabular}{|lccc|}
\hline & $\begin{array}{c}\text { Larval fish } \\
\text { abundance }\end{array}$ & $\begin{array}{c}\text { Species } \\
\text { richness }\end{array}$ & $\begin{array}{c}\text { Diversity } \\
\text { index }\end{array}$ \\
\hline Intercept & $93.8(11.5)^{* * *}$ & $38.0(4.7)^{* * *}$ & $5.4(0.6)^{* * *}$ \\
$\begin{array}{l}\text { Depth } \\
\text { SST }\end{array}$ & $-0.9(0.2)^{* * *}$ & $-0.7(0.1))^{* * *}$ & $-1.5(0.2)^{* * *}$ \\
GV & $-82.3(10.3)^{* * *}$ & $-33.1(4.2)^{* *}$ & \\
MeB & $0.4(0.2)^{*}$ & $0.3(0.1)^{* * *}$ & $-0.6(0.2)^{* *}$ \\
$\mathrm{R}^{2}{ }_{\text {adj }}$ & 0.63 & 0.75 & 0.39 \\
$\mathrm{p}$ & 0.000 & 0.000 & 0.000 \\
Residual SE & 0.42 & 0.17 & 0.55 \\
of estimate & & & 71 \\
df & 70 & 69 & \\
\end{tabular}



Fig. 8. Horizontal distribution of (a) species richness (the number of larval fish taxa) and (b) larval fish diversity (Shannon-Wiener diversity index). Black dots represent sampling stations 

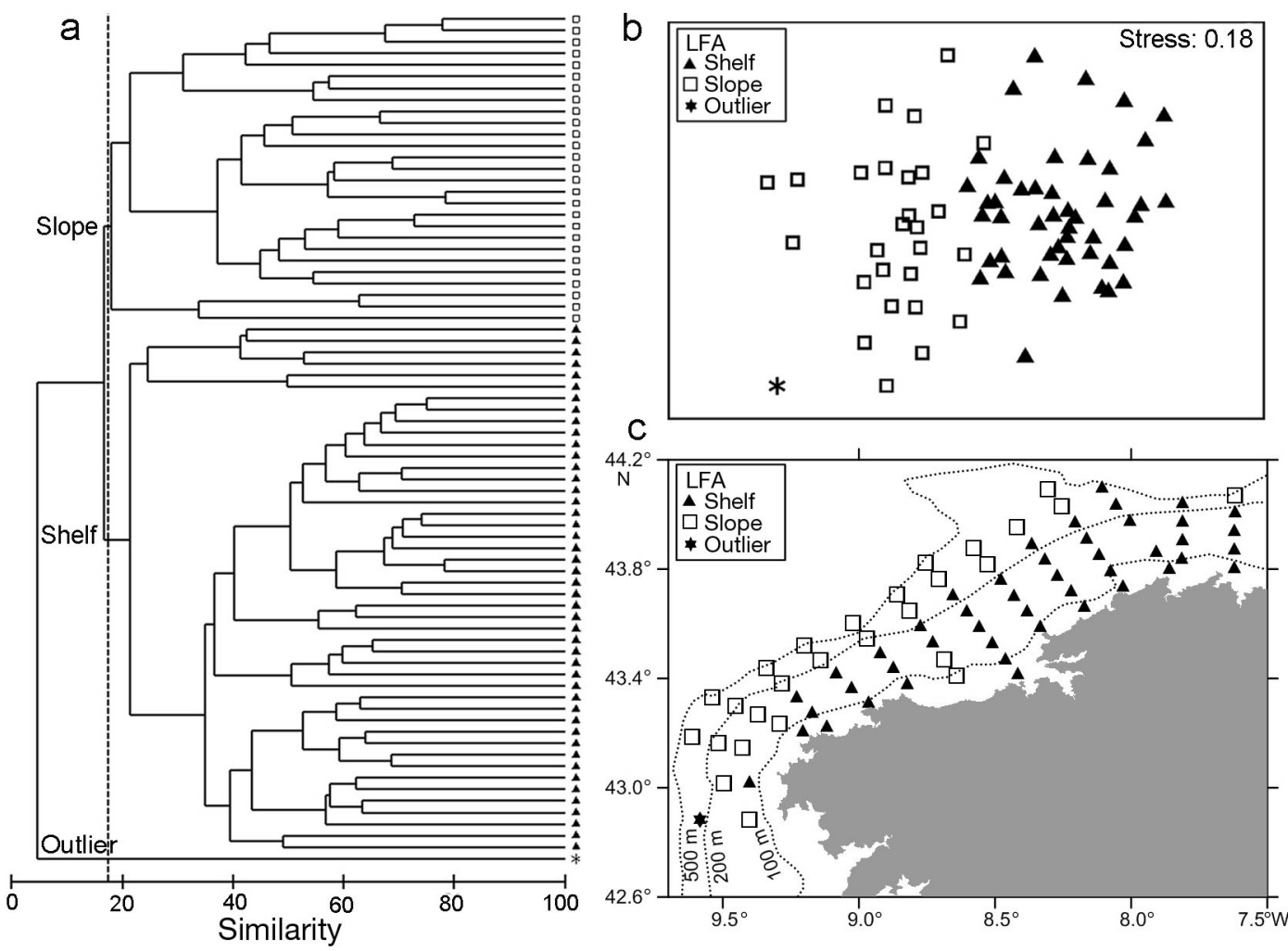

Fig. 9. (a) Hierarchical clustering and (b) non-metric multidimensional scaling (nMDS) ordination of the ichthyoplankton stations based on the Bray-Curtis similarity matrix of square root transformed abundance of fish larvae. (c) Geographical location of the larval fish assemblages (LFA) defined by cluster classification and nMDS ordination they occupied, viz. 'shelf' and 'slope' assemblages. The shelf assemblage, with the exception of a station at $223 \mathrm{~m}$ depth, included sites located inside or over the $200 \mathrm{~m}$ isobath (Fig. 9c). The slope assemblage was not as well defined geographically, especially in the southern part of the study area where it included several stations located inside the $200 \mathrm{~m}$ isobath



(Fig. 9c). The outer station of Transect I (Fig. 1) was not allocated to either of those 2 assemblages and was considered an outlier (asterisk in Fig. 9b,c). Cluster analysis and nMDS ordination also identified 2 taxon groups, viz. the shelf and slope taxon groups, named after the habitat of the adult fish species that dominated each of them (Fig. 10). The shelf group

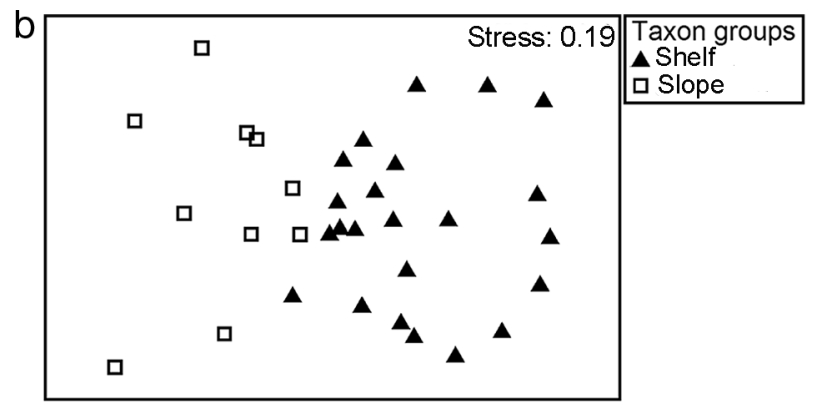

Fig. 10. (a) Hierarchical clustering and (b) non-metric multidimensional scaling ordination of larval fish taxa based on the Bray-Curtis similarity matrix of square root transformed abundance of fish larvae 


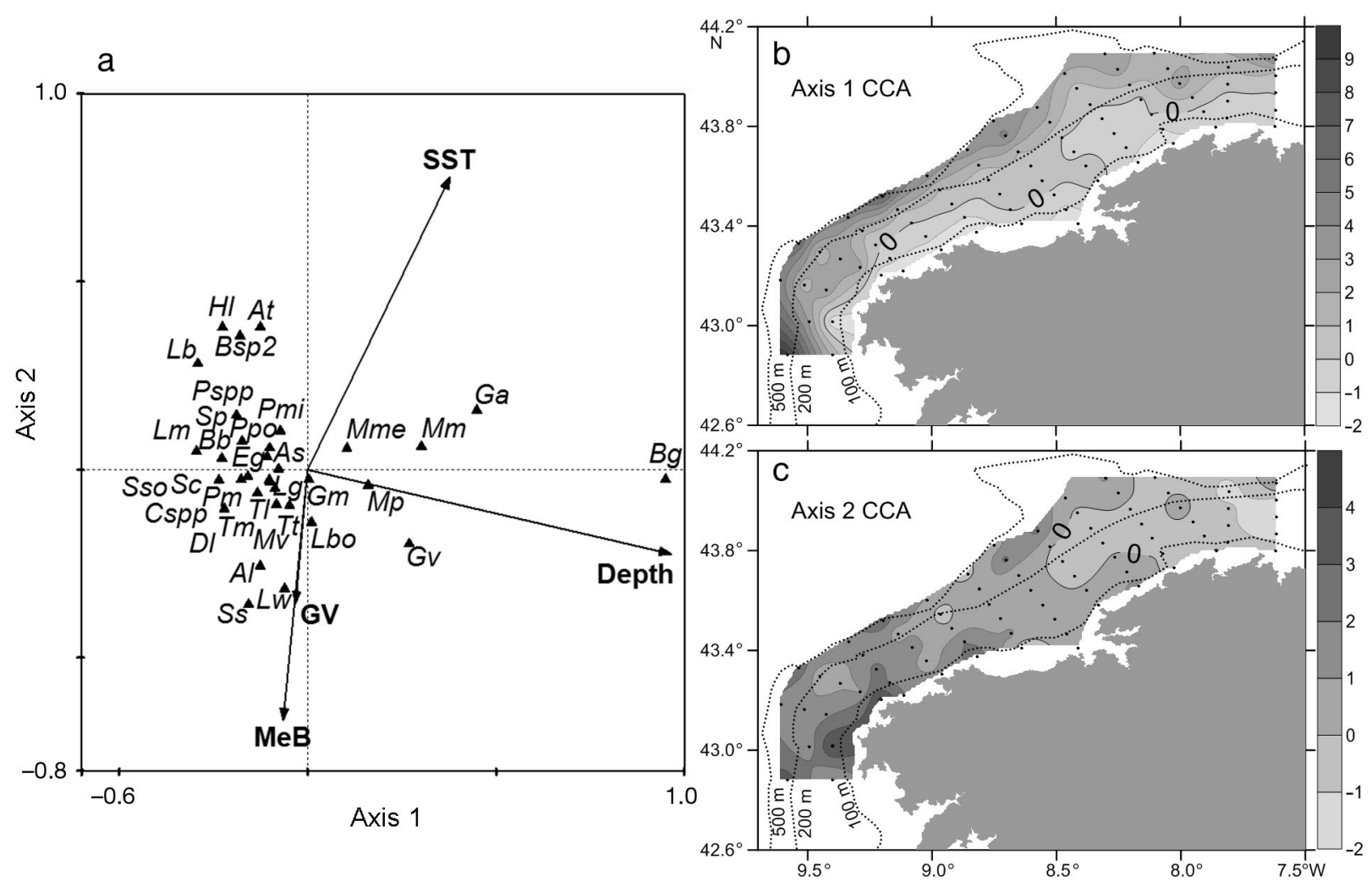

Fig. 11. (a) Canonical correspondence analysis (CCA) biplot for environmental variables (arrows) and larval fish taxa (triangles). Environmental variables were depth, sea surface temperature (SST), mesozooplanton biomass (MeB) and geostrophic velocity (GV). See Table 1 for larval fish taxon codes. (b,c) Geographical distribution of axes 1 and 2 CCA scores. Lines marked ' 0 ' separate positive and negative station scores. Black dots represent sampling stations

was formed by larvae of those species that as adults inhabit the neritic region and also reproduce there. The slope group was not as well defined because it included oceanic (Benthosema glaciale) and oceanicslope species (M. muelleri), but also some shelfdwelling (e.g. Arnoglossus laterna and Gaidropsaurus vulgaris) species.

\section{Relationship between environmental variables and larval fish species}

The Monte Carlo permutation test showed that only 4 environmental variables (depth, SST, GV and MeB) were significant $(p<0.05)$ in explaining larval fish species distribution. Of these variables, depth and SST were the most important. The first 2 canonical axes (axis 1 and axis 2) were also significant ( $<<$ 0.01 ), explaining $88.2 \%$ of the variance of the species-environment relationship. The species-environment correlation coefficients for the first 2 CCA axes were 0.82 for axis 1 , and 0.78 for axis 2. Depth and SST were positively correlated with axis 1 , whereas
$\mathrm{MeB}$ and GV were negatively correlated with this axis (Fig. 11). The geographical representation of axis scores confirms that axis 1 was mainly determined by depth (Fig. 11). Accordingly, slope spawning taxa appeared on the right side of this axis (Fig. 11). In fact, the only strictly oceanic species included in this analysis (B. glaciale) was located at the very right side of this axis (Fig. 11). Neritic taxa clustered on the left side of the ordination biplot where they were distributed along axis 2 (Fig. 11). The geographical representation of axis scores shows that axis 2 was mainly determined by SST (Figs. 11 \& 3). Hence, S. scombrus, which was found only in the coldest part of the study area (Figs. $3 \& 6$ ), was located on the left side of the ordination biplot and on the negative side of axis 2 , farther away from the centre of the CCA biplot (Fig. 11). S. pilchardus, which was widely distributed along the coastal region (Fig. 6), was also located on the left side of the ordination biplot but close to the centre of the biplot (Fig. 11). Moreover, the 2 taxon groups defined by cluster and nMDS analyses (Fig. 10) also appeared in the CCA biplot (Fig. 11) with relatively little difference. 


\section{DISCUSSION}

\section{Hydrography and its influence on the horizontal distribution of fish larvae}

The well mixed water column corresponds to the typical winter situation of temperate regions. On the other hand, according to 'spiciness' values, the study area south of Cape Prior was occupied by the warmer and saltier ENACWst, transported by the IPC, while the area north of the cape represented the transition zone between the ENACWst and the colder and fresher ENACWsp. Thus, the subsurface front observed in this study originated in the confluence of these 2 water masses. In the surface layer, the transition is seen in the change in the along-shelf gradient in SST and SSS around Cape Prior, and in the significant differences in SST and SSS on either side of the cape. The front also seems to have important implications for the LFC, as discussed below.

The surface currents over the shelf and slope respond to atmospheric forcing. Thus, the north-easterly current over the slope at the beginning of the cruise resulted from the predominance of upwellingfavourable winds during the month prior to the cruise, which would have displaced the IPC off the shelfbreak (Peliz et al. 2002). As the cruise progressed, southerly winds favourable to downwelling were responsible for the increase in the along-shelf poleward flow and for its approach to the coast, similar to situations reported by Peliz et al. (2003) and Torres \& Barton (2007). During the last days of the cruise, when wind was changing back to upwellingfavourable, it was not possible to detect any dominant alongshore current, probably because the system had not had time to respond, given the estimated response time of $3 \mathrm{~d}$ for the Galician coast (McClain et al. 1986).

Despite the variability in wind speed and direction and the resulting variability in the hydrographic conditions, Rodriguez et al. (2015) concluded that the average hydrographic conditions during the period of study were of downwelling. The higher concentration of fish larvae found in the frontal region was consistent with downwelling conditions during this time. Fish eggs and larvae, transported by the surface poleward flow associated with coastal downwelling (Santos et al. 2004, 2007), would be retained in the frontal region, where eggs may hatch. The northward increase in larval sizes of coastal spawning species (apart from Sardina pilchardus) supports their poleward transport. The capture of practically all Scomber scombrus larvae in the northeastern-most stations would also support this transport. However, the horizontal distribution of fish eggs collected during this cruise shows that abundances were relatively low in the south, increasing northwards and reaching the highest values in the northernmost part of the study area (P. Alvarez unpubl. data). This, along with the erratic pattern of surface currents found at the end of the cruise, when the northernmost study area was sampled, suggest that fish spawning was also occurring in the frontal region. Relatively important spawning was previously recorded by Rodriguez et al. (2009) in a cross-shelf frontal region located around Cape Estaca de Bares. In short, the concentration of fish larvae found in the frontal region was probably the result of both fish spawning and larval transport. The importance of frontal regions for fish spawning has already been suggested (e.g. Bakun 1998, 2006, Munk et al. 2009), and the concentration of fish larvae in these regions is also well documented (e.g. Sabatés 1990, Govoni \& Grimes 1992). Therefore, the association of fish larvae with the coldest part of the frontal region, rather than with the lowest SST itself, would account for the significant proportion of variance in larval fish abundance and species richness explained by temperature. The effect of SST in the horizontal distribution of fish larvae should be negligible, since the difference between the maximum and minimum SST values was only $0.61^{\circ} \mathrm{C}$.

To explain the contrasting along-shelf distribution shown by the larval sizes of $S$. pilchardus, larval age must be taken into account. Considering a size at hatching of between 3.3 and $4.0 \mathrm{~mm}$ (Russell 1976) and a linear growth rate of $0.49 \mathrm{~mm} \mathrm{~d}^{-1}(\operatorname{Re} 1984)$, the average age would be around $13 \mathrm{~d}$ for larvae captured in the south (transect group I-V), $9.5 \mathrm{~d}$ for those caught in the central area (transect group VI-X) and $6 \mathrm{~d}$ for those caught in the north (transect group XI-XV). This age distribution suggests that larvae caught in the south and central areas were likely transported from the frontal region, where relatively strong spawning for this species was previously recorded (Rodriguez et al. 2009), by the surface equatorward flow associated with coastal upwelling (Wooster et al. 1976, Haynes \& Barton 1990), which dominated during the days before the survey. The age of the larvae caught in the north suggests that these larvae hatched when coastal downwelling conditions dominated and were retained in the region of the front. The changes between upwelling and downwelling conditions during the cruise and the ensuing changes in direction of the surface flow over the shelf could also have 
been responsible for the concentration of larger larvae of slope spawning species in the central part of our study area.

The importance of depth in explaining variance in larval fish abundance and species richness is consistent with the spawning location of most taxa caught in this study, most of them shelf-dwelling species which, as such, reproduce in the shelf region (Whitehead et al. 1984-1986, Froese \& Pauly 2013). Accordingly, larval fish abundance and species richness decreased with increasing depth. However, the influence of circulation on the cross-shelf distribution of fish larvae must be taken into account. Notably, the surface onshore Ekman flow associated with coastal downwelling, by retaining larvae of coastal-shelf spawning species (e.g. S. pilchardus, S. scombrus and Trisopterus minutus) near shore and by spreading larvae of slope spawning species (e.g. Maurolicus muelleri, Merluccius merluccius and Micromesistius poutassou) over the shelf (Rodriguez et al. 2015), would account for the observed patterns of crossshelf distribution shown by fish larvae. The concentration of larger larvae of coastal-shelf spawning species in the 100-200 m depth stratum would support their retention over the shelf. The ability of fish larvae to control their vertical distribution (Leis 2006) would allow larvae to avoid sinking associated with coastal downwelling and, consequently, the offshore transport by the subsurface offshore flow associated with it. The shoreward increase in larval size of slope spawning species is consistent with transport towards the coast. This transport along with the associated retention of coastal-shelf spawning species over the shelf would have exaggerated the importance of depth to the variability in larval fish abundance and species richness.

The cross-shelf structuring of the LFC into 2 assemblages, which has been widely reported (e.g. Richardson \& Pearcy 1977, Somarakis et al. 2002, Moyano et al. 2014), indicates that depth was the most important variable in shaping the horizontal structure of the LFC. This is supported by CCA results which identified depth as the most important variable in explaining species distribution. Although depth is apparently the most important variable in defining larval fish assemblages, the maintenance of assemblage boundaries, besides larval behaviour, would depend on the hydrographic processes in the area (Cowen et al. 1993). In this sense, the single assemblage found by Rodriguez et al. (2009) in this region would correspond to our shelf assemblage. The presence of a single larval fish assemblage was attributed by these authors to offshore Ekman transport, associated with a coastal upwelling event, which would have transported neritic larvae offshore, thus homogenising the LFC in the cross-shelf direction. In consequence, the assemblages found in the present study could have been the end result of the interaction between depth, or fish spawning location, and the hydrographic conditions of coastal downwelling found during the survey. This interaction, by keeping fish larvae of shelfcoastal spawning species close to the coast, would have maintained assemblage boundaries. That is to say, fish larvae would have acted as tracers of hydrographic processes across the shelf (coastal downwelling) at the short-term ( $10 \mathrm{~d})$ scale of the survey. The concentration of fish larvae in the frontal area and the along-shelf distribution of $S$. pilchardus larval sizes supports the role of fish larvae as hydrographic tracers in the region at the time of the study. The use of fish larvae as tracers of hydrography has been proposed elsewhere, e.g. Australian waters (Smith \& Suthers 1999), the NW African upwelling region (Rodriguez et al. 1999), the Sicilian channel (Garcia Lafuente et al. 2002) and the Taiwan Strait (Hsieh et al. 2012). Close to the present region, $14 \mathrm{yr}$ of monthly sampling of the same transect off the central coast of northern Spain demonstrated that, during February and March, fish larvae of M. poutassou (a slope-spawning species) are good tracers of the intrusion of the IPC onto the shelf (Rodriguez 2008, unpubl. data). For its part, the vertical distribution of larval sizes of $M$. merluccius, $M$. poutassou, $M$. variegatus and T. minutus found during this study suggests ontogenetic ascent in the water column (Rodriguez et al. 2015). This upward movement could place larger larvae within the Ekman layer associated with coastal downwelling and therefore favour their retention (neritic spawning species) or their coastward transport (oceanic slope-spawning species). Therefore, fish larvae in the region during the winter mixing period could be considered as 'active' tracers (sensu Smith \& Suthers 1999) of mesoscale hydrographic processes.

\section{LFC}

The number of larval fish taxa identified in an ichthyoplankton study depends on the availability of taxonomic information to identify fish larvae to species level and on the ability of the ichthyoplankton taxonomists to use this information. Therefore, the LFC parameters, viz. species richness and larval fish diversity, must be regarded with caution. Species richness values recorded in this study were relatively 
high, even higher than those recorded by Rodriguez et al. (2009) in spring along the NW and northern Iberian Peninsula coast, or in nearby regions in spring (Garrido et al. 2009) and summer (John \& Re 1995, Rodriguez et al. 2011), when most species reproduce in the NE Atlantic region (Russell 1976, Whitehead et al. 1984-1986). These relatively high values may be explained by 2 facts: (1) larvae of many fish species in the nearby central Cantabrian (Rodriguez 2008) and southern Galician regions (J. M. Rodriguez unpubl. data) begin to appear in the plankton samples during late winter and early spring (February to March); and (2) the intensive sampling carried out may have ensured collecting larvae of most species that were spawning at the time of this study.

The composition and structure of the LFC roughly agree with the composition and structure of the adult fish population of the area, although with a significant exception with respect to the structure. The LFC was dominated by 3 species (M. poutassou, S. scombrus and M. merluccius) that are important components of the adult fish population of the region (Casey \& Pereiro 1995, Carrera et al. 2001, ICES 2013). The exception was the relatively low abundance shown by $S$. pilchardus, the pelagic fish species most abundant in the region (ICES 2013). The dominance of $M$. poutassou was expected because this study was carried out during the relatively short (February-March) but intense spawning period of this species off the Iberian coasts (Whitehead et al. 1984-1986, Rodriguez 2008). This study also coincided with the main spawning period of $M$. merluccius in the region (Mehault et al. 2010) and with the beginning of the spawning period of $S$. scombrus in the NE Atlantic (Whitehead et al. 1984-1986). This is supported by the fact that all $S$. scombrus larvae were collected at the very end of the cruise and by their average size $(2.7 \mathrm{~mm})$, which corresponds to lecithotrophic larvae (Russell 1976). In the case of $S$. pilchardus, this study was carried out during a period of low larval abundance off the NW and northern Iberian peninsula (Rodriguez 2008, unpubl. data), In brief, fish larvae collected during a single sampling cruise give a snapshot of the composition of the adult fish population that is spawning at the time of the sampling, but continuous monitoring of ichthyoplankton is necessary to gain a relatively accurate idea of the composition and structure of the adult fish population inhabiting a region.

Total larval fish abundance was relatively high for the area of study. However, to our knowledge, no previous information is available on the larval fish abundance in this or nearby regions during the winter mixing period with which to compare our results. On the other hand, the strong positive correlation of larval fish abundance with species richness indicates that the increase in larval fish abundance was related with the increase in the number of species that made up the LFC rather than with the proliferation of a single or a few species.

The third variable in explaining larval fish abundance variability, after SST and depth, was MeB. However, Rodriguez et al. (2015) found that mesozooplankton and fish larvae were relatively segregated in the vertical plane. Thus, the relationship between these plankton components could have arisen from the horizontal coincidence between them. Nevertheless, trophic interaction cannot be ruled out because at least two of the most abundant species of fish larvae caught in this study consume mesozooplankton; $M$. poutassou larvae feed on relatively large zooplankton prey (Hillgruber et al. 1997) and even first feeding larvae of $M$. merluccius feed on mesozooplankton (Morote et al. 2011).

The small amount of variance of larval fish diversity accounted for by the 2 variables included in the regression model, i.e. depth and GV, indicates that variables other than those considered in this study played a role. The importance of depth in explaining the larval fish diversity variance should be expected because of the strong relationship of larval fish diversity with species richness and the importance of depth in explaining the variance in species richness. The negative effect of GV on larval fish diversity could be related to the occurrence of the highest GV at the northeastern border of the study area (Fig. 3), coincident with the highest larval fish abundance. Moreover, this relatively high larval fish abundance was mainly the result of the proliferation of a few species, as can be seen in Fig. 6, which involves low larval fish diversity values.

In summary, during the late winter season, the NW Iberian upwelling region supports a relatively abundant and diverse larval fish community, which to some extent reflects the composition and structure of the adult fish population of the region. Results of this study suggest that larval fish assemblages in the region are driven by coastal downwelling during the winter mixing period, and support our hypothesis that fish larvae are good tracers, over a short term (around $10 \mathrm{~d}$ ), of the hydrography of the region during this period. Our results also indicate that one must be cautious when interpreting the influence of environmental variables on ichthyoplankton distribution. 
Acknowledgements. We greatly appreciate the assistance of the crew of the RV 'Cornide de Saavedra' and all the participants in the 'Cramer 1203 cruise' We recognize the contribution of 3 anonymous reviewers who provided helpful reviews of the manuscript that enabled us to improve this paper. The constructive review by Dr. E.D. Barton is specially appreciated. This work was funded by the Spanish research project CRAMER (CTM2010-21856-CO3-02) and by the Galician research project ECOPREGA (10MMA602021PR). The open access publication of this paper was funded by the Principado de Asturias research project GRUPIN14-144.

\section{LITERATURE CITED}

Auth TD, Brodeur RD (2006) Distribution and community structure of ichthyoplankton off the coast of Oregon, USA, in 2000 and 2002. Mar Ecol Prog Ser 319:199-213

Azeiteiro UM, Bacelar-Nicolau L, Resende P, Gonçalves P, Pereira MJ (2006) Larval fish distribution in shallow coastal waters off North Western Iberia (NE Atlantic). Estuar Coast Shelf Sci 69:554-566

Bakun A (1998) Ocean triads and radical interdecadal variation: bane and boon to scientific fisheries management. In: Pitcher T, Pauly D, Hart PB (eds) Reinventing fisheries management, Book 23. Springer, Dordrecht, p 331-358

Bakun A (2006) Fronts and eddies as key structures in the habitat of marine fish larvae: opportunity, adaptive response and competitive advantage. Sci Mar 72S:105-122

Carrera P, Meixide M, Porteiro C, Miquel J (2001) Study of the blue whiting movements around the Bay of Biscay using acoustic methods. Fish Res 50:151-161

Casey J, Pereiro FJ (1995) European hake (M. merluccius) in the North-East Atlantic. In: Alheit J, Pitcher TJ (eds) Hake: fisheries, ecology and markets. Fish and Fisheries Series, Vol 15. Chapman and Hall, London, p 125-147

Clarke RK (1993) Non-parametric multivariate analyses of changes in community structure. Aust J Ecol 18:117-143

Clarke RK, Warwick RM (2001) Changes in marine communities: an approach to statistical analysis and interpretation, 2nd edn. PRIMER-E, Plymouth

Cowen RK, Hare JA, Fahay MP (1993) Beyond hydrography: Can physical processes explain larval fish assemblages within the Middle Atlantic Bight? Bull Mar Sci 53: 567-587

Ferreiro MJ, Labarta U (1988) Distribution and abundance of teleostean eggs and larvae on the NW coast of Spain. Mar Ecol Prog Ser 43:189-199

Field JG, Clarke KR, Warwick RM (1982) A practical strategy for analysing multispecies distribution patterns. Mar Ecol Prog Ser 8:37-52

Flament P (2002) A state variable for characterizing water masses and their diffusive stability: spiciness. Prog Oceanogr 54:493-501

Froese R, Pauly D (eds) (2013) FishBase. www.fishbase.org

Garcia A, Franco C, Sola A (1992) Sardine, Sardina pilchardus (Walb.), egg and larval distribution off the Spanish North Atlantic coast (Galician and Cantabrian areas) in April 1987. Bol Inst Esp Oceanogr 8:87-96

Garcia Lafuente J, García A, Mazzola S, Quintanilla L, Delgado J, Cuttitta A, Patti B (2002) Hydrographic phenomena influencing early life stages of the Sicilian Channel anchovy. Fish Oceanogr 11:31-44
Garrido S, Santos AMP, dos Santos A, Re P (2009) Spatial distribution and vertical migrations of fish larvae communities off Northwestern Iberia sampled with LHPR and Bongo nets. Estuar Coast Shelf Sci 84:463-475

> Gonzalez-Nuevo G, Nogueira E (2005) Intrusions of warm and salty waters onto the NW and N Iberian shelf in early spring and its relationship to climate variability. J Atmos Ocean Sci 10:361-375

Gonzalez-Nuevo G, Nogueira E, Valdés L (2007) Spring influence of the Iberian Poleward Current into the Bay of Biscay from 1987 to 2006. Globec Int Newsl April 2007: $1-2$

> Govoni JJ (2005) Fisheries oceanography and the ecology of early life histories of fishes: a perspective over fifty years. Sci Mar 69(Suppl 1):125-137

Govoni JJ, Grimes CB (1992) The surface accumulation of larval fishes by hydrodynamic convergence within the Mississippi River plume front. Cont Shelf Res 12: 1265-1276

- Haynes R, Barton ED (1990) A poleward flow along the Atlantic coast of the Iberian peninsula. J Geophys Res 95: 11425-11441

> Hillgruber N, Kloppmann ME, Wahl E, von Westernhagen $\mathrm{H}$ (1997) Feeding of larval blue whiting and Atlantic mackerel: a comparison of foraging strategies. J Fish Biol 51(Suppl sA):230-249

> Hsieh HY, Lo WT, Wu LJ, Liu DC (2012) Larval fish assemblages in the Taiwan Strait, western North Pacific: linking with monsoon-driven mesoscale current system. Fish Oceanogr 21:125-147

ICES (International Council for the Exploration of the Sea) (2013) Report of the Working Group on Ecosystem Assessment of Western European Shelf Seas (WGEAWESS), 11-15 February 2013, Lisbon, Portugal. ICES CM 2013/ SSGRSP:02. ICES, Copenhagen

John HC, Re P (1995) Cross-shelf zonation, vertical distribution and drift of fish larvae off northern Portugal during weak upwelling. Arquivos do Museu Bocage Nova Serie Vol 2. Museu Bocage, Lisbon, p 607-632

> Leis JM (2006) Are larvae of demersal fishes plankton or nekton? Adv Mar Biol 51:57-141

Lindo-Atichati D, Bringas F, Goni G, Muhling B, MullerKarger FE, Habtes S (2012) Varying mesoscale structures influence larval fish distribution in the northern Gulf of Mexico. Mar Ecol Prog Ser 463:245-257

Lopez-Jamar E (1977) Estudio preliminar del ictioplancton de la ria de Arosa. Bol Inst Esp Oceanogr 2:41-74

Lopez-Jamar E, Coombs SH, Garcia A, Halliday NC, Knust $\mathrm{R}$, Nellen W (1995) The distribution and survival of larvae of sardine Sardina pilchardus (Walbaum, 1792) off the north and north-western Atlantic coast of the Iberian Peninsula, in relation to environmental conditions. Bol Inst Esp Oceanogr 11:27-46

McClain CR, Chao SY, Atkinson LP, Blanton JO, Fernandez de Castillejo F (1986) Wind-driven upwelling in the vicinity of Cape Finisterre, Spain. J Geophys Res 91: 8470-8486

Mehault S, Dominguez-Petit R, Cerviño S, Saborido-Rey F (2010) Variability in total egg production and implications for management of the southern stock of European hake. Fish Res 104:111-122

Morote E, Olivar MP, Bozzano A, Villate F, Uriarte I (2011) Feeding selectivity in larvae of the European hake (Merluccius merluccius) in relation to ontogeny and visual capabilities. Mar Biol 158:1349-1361 
Moyano M, Rodriguez JM, Hernandez-Leon S (2014) Larval fish distribution and retention in the Canary Current system during the weak upwelling season. Fish Oceanogr 23:191-209

> Munk P, Fox CJ, Bolle LJ, Van Damme CJG, Fossum P, Kraus G (2009) Spawning of North Sea fishes linked to hydrographic features. Fish Oceanogr 18:458-469

Norcross BL, Shaw RF (1984) Oceanic and estuarine transport of fish eggs and larvae: a review. Trans Am Fish Soc 113:153-165

Olivar MP, Sabatés A (1997) Vertical distribution of fish larvae in the north-west Mediterranean Sea in spring. Mar Biol 129:289-300

Olivar MP, Emelianov M, Villate F, Uriarte I, Maynou F, Alvarez I, Morote E (2010) The role of oceanographic conditions and plankton availability in larval fish assemblages off the Catalan coast (NW Mediterranean). Fish Oceanogr 19:209-229

Otero P, Ruiz-Villarreal M, Garcia-Garcia L, GonzalezNuevo G, Cabanas JM (2013) Coastal dynamics off Northwest Iberia during a stormy winter period. Ocean Dyn 63:115-129

Paris CB, Cowen RK (2004) Direct evidence of a biophysical retention mechanism for coral reef fish larvae. Limnol Oceanogr 49:1964-1979

Parrish RH, Nelson CR, Bakun A (1981) Transport mechanisms and reproductive success of fishes in the California Current. Biol Oceanogr 1:175-203

Peliz A, Rosa T, Santos AMP, Pissarra J (2002) Fronts, jets, and counter-flows in the Western Iberia Upwelling System. J Mar Syst 35:61-77

Peliz A, Dubert J, Haidvogel DB, Le Cann B (2003) Generation and unstable evolution of a density-driven eastern poleward current: the Iberian Poleward Current. J Geophys Res 108:3268

R Development Core Team (2014) R: a Language and environment for statistical computing. R Foundation for Statistical Computing, Vienna. Available at www.rproject.org

Re P (1984) Evidence of daily and hourly growth in pilchard larvae based on otolith growth increments, Sardina pilchardus (Walbaum, 1972). Cybium 8:33-38

Relvas P, Barton ED, Dubert J, Oliveira PB, Peliz A, da Silvae JCB, Santos AMP (2007) Physical oceanography of the western Iberia ecosystem: latest views and challenges. Prog Oceanogr 74:149-173

Richardson SL, Pearcy WG (1977) Coastal and oceanic fish larvae in an area of upwelling off Yaquina Bay, Oregon. Fish Bull 75:125-145

Rodriguez JM (2008) Temporal and cross-shelf distribution of ichthyoplankton in the central Cantabrian Sea. Estuar Coast Shelf Sci 79:496-506

Rodriguez JM, Hernandez-Leon S, Barton ED (1999) Mesoscale distribution of fish larvae in relation to an upwelling filament off Northwest Africa. Deep-Sea Res I 46:1969-1984

Rodriguez JM, Gonzalez-Nuevo G, Gonzalez-Pola C, Cabal

Editorial responsibility: Alejandro Gallego,

Aberdeen, UK
J (2009) The ichthyoplankton assemblages and the environmental variables off the NW and N Iberian Peninsula coasts, in early spring. Cont Shelf Res 29:1145-1156

> Rodriguez JM, Gonzalez-Pola C, Lopez-Urrutia A, Nogueira E (2011) Composition and daytime vertical distribution of the ichthyoplankton assemblage in the Central Cantabrian Sea shelf, during summer: an Eulerian study. Cont Shelf Res 31:1462-1473

Rodriguez JM, Cabrero A, Gago J, Guevara-Fletcher C and others (2015) Vertical distribution and migration of fish larvae in the NW Iberian upwelling system during the winter mixing period: implications for cross-shelf distribution. Fish Oceanogr 24:274-290

Russell FS (1976) The eggs and planktonic stages of British marine fishes, Academic Press, London

Sabatés A (1990) Distribution pattern of larval fish populations in the northwestern Mediterranean. Mar Ecol Prog Ser 59:75-82

Santos AMP, Peliz A, Dubert AJ, Oliveira PB, Angelico MM, Re P (2004) Impact of a winter upwelling event on the distribution and transport of sardine (Sardina pilchardus) eggs and larvae off western Iberia: a retention mechanism. Cont Shelf Res 24:149-165

Santos AMP, Chicharo A, Dos Santos A, Moita T, Oliveira PB, Peliz A, Re P (2007) Physical-biological interactions in the life history of small pelagic fish in the Western Iberia Upwelling Ecosystem. Prog Oceanogr 74:192-209

Smith KA, Suthers IM (1999) Displacement of diverse ichthyoplankton assemblages by a coastal upwelling event on the Sydney shelf. Mar Ecol Prog Ser 176:49-62

Smith KA, Gibbs MT, Middleton JH, Suthers IM (1999) Short term variability in larval fish assemblages of the Sydney shelf: tracers of hydrographic variability. Mar Ecol Prog Ser 178:1-15

Somarakis S, Drakopoulos P, Filippou V (2002) Distribution and abundance of larval fish in the northern Aegean Sea-eastern Mediterranean-in relation to early summer oceanographic conditions. J Plankton Res 24:339-358

ter Braak CJF, Smilauer P (2002) CANOCO reference manual and CanoDraw for Windows user's guide: software for canonical community ordination (version 4.5), Microcomputer Power, Ithaca, NY

> ter Braak CJF, Verdonschot PFM (1995) Canonical correspondence analysis and related multivariate methods in aquatic ecology. Aquat Sci 57:255-289

> Torres R, Barton ED (2007) Onset of the Iberian upwelling along the Galician coast. Cont Shelf Res 27:1759-1778

> Torres R, Barton ED, Miller P, Fanjul E (2003) Spatial patterns of wind and sea surface temperature in the Galician upwelling region. J Geophys Res 108:3130-3144

Whitehead PJP, Bauchot ML, Hureau JC, Nielsen J, Tortonesse EE (eds) (1984-1986) Fishes of the North-eastern Atlantic and the Mediterranean, Vols I-III. UNESCO, Paris

Wooster W, Bakun A, McLain DR (1976) The seasonal upwelling cycle along the eastern boundary of the North Atlantic. J Mar Res 34:132-141

Submitted: November 14, 2014; Accepted: March 13, 2015 Proofs received from author(s): July 23, 2015 